\title{
А.С. Миронов
}

Московский государственный институт культуры, 141406 г. Химки, Московская область, Российская Федерация

\section{Уникальный концепт славы: девальвация ценности личной славы (молвы) в русском былинном эпосе}

\begin{abstract}
Аннотация. Статья посвящена концепту славы, одному из центральных в мировом эпическом фольклоре. Как показывают результаты анализа, осуществленного автором на основе аксиологического, сравнительно-исторического и историко-генетического методов, слава в подавляющем большинстве случаев - в "Илиаде» и "Одиссее» Гомера, «Махабхарате», европейских и восточных средневековых эпосах - соотносится с молвой о конкретном герое и понимается как специфический субститут индивидуального бессмертия или же как залог посмертного блаженства. Принципиальное исключение из этого правила обнаруживает русский былинный эпос: былины не мыслят славу как специфический атрибут того или иного персонажа, но как коллективное свойство всего русского богатырства - свойство, призванное удержать иноземных владык от вторжений на Русь и обеспечить защиту на земле Божьих установлений и страдающего человека. Предпринятое в статье сопоставление разнообразных памятников героического фольклора с русскими былинами позволяет полнее осветить как аксиологический строй, характерный для эпической традиции в целом (понятия славы, чести, хвастовства и молвы все еще остаются недостаточно разработанными в научной литературе и уточняются в настоящей работе), так и определить принципиальную специфику былинного эпоса, его уникальное положение в ряду прочих памятников. В частности, сопоставление героических песен, созданных в христианской Европе, с русскими былинами позволяет аргументированно утверждать, что именно последние наиболее полно и оригинально - на разных уровнях художественной структуры (сюжет, мотивы, образные ряды) - воплотили в себе ценности и идеи христианства, его духовно-нравственный потенциал.
\end{abstract}

Ключевые слова: фольклор, эпос, былины, эпическое сознание, роль ценностей в эпической культуре, эпический концепт личной славы, ценностный центр героя, эпическое хвастовство

\section{A.S. Mironov}

Moscow State Institute of Culture, Khimki, 141406, Moscow region, Russian Federation

\section{The unique concept of glory: Devaluation of the value of personal fame in the Russian folk epics}

\begin{abstract}
The article is dedicated to the concept of glory, which should be placed among the main concepts of the world's folk epics. According to the author's analysis (undertaken through the axiological, comparative-historical, and historical-genetic methods), glory as rendered in Homer's lliad and Odyssey, The Mahābhārata, European and Oriental medieval epics, etc. - is most often related to the rumors about a concrete hero and emerges as a substitute of individual immortality or as a pledge of postmortem beatitude. Among nearly all known works of heroic poetry, only the Russian folk epics are fundamentally opposed to this interpretation: Bylinas don't treat glory as a specific attribute belonging to this or that hero, but as a collective virtue of all Russian knights - the one intended to deter foreign rulers from their invasions of Russia and to protect, in this earthly world, both the divine law and suffering people. Accordingly, the article provides a comparison between different works of heroic
\end{abstract}


folklore and Russian bylinas, which enables both to interpret more fully the axiological structure of the epic tradition as such (the notions of glory, honor, boasting, and rumor - the ones still insufficiently analyzed in scholarly literature and defined more precisely in the present paper), and to determine the principal originality of the Russian folk epics, their unique position among other oral songs of similar nature. In particular, a comparison between the heroic songs of Christian Europe and Russian bylinas allows the author to argue confidently that precisely the latter incarnated (in the most original and profound way, at different levels of their artistic structure, including plot, motives, and imagery) the values and the ideas of Christianity, its spiritual and moral potential.

Key words: folklore, epic, bylinas, epic consciousness, role of values in the epic culture, the epic concept of personal fame, epic hero's value-center, epic boasting 